J-SANAK: Jurnal Kajian Anak

(p-ISSN: 2686-5343 |e-ISSN: 2715-7989)

Vol. (3)(01), (Juli-Desember)(2021), (Halaman)(48-57)

DOI: https://doi.org/10.24127/j-sanak.v3i01.1404

\title{
PERKEMBANGAN GERAK DASAR ANAK DI MASA PANDEMI COVID-
} 19

\author{
Nurmela Farepsi ${ }^{1}$ \\ Universitas Negeri Padang \\ nurmelafarepsi08@gmail.com
Dadan Suryana ${ }^{2}$
Universitas Negeri Padang \\ suryana@fip.unp.ac.id
}

\begin{abstract}
ABSTRAK
Penelitian ini bertujuan untuk mengetahui perkembangan gerak dasar anak dimasa pandemi covid-19 di TK Negeri Pembina Lengayang. Penelitian ini berjenis kualitatif deskriptif. Subjek penelitian ialah anak-anak kelas B1. Informan penelitian ini adalah guru kelas B1. Pengumpulan data dilakukan dengan menggunakan catatan lapangan, wawancara, dan dokumentasi. Analisis data dilakukan dengan mengikuti langkah-langkah dari Miles Huberman, yakni: (1) pengumpulan data; (2) reduksi data; (3) penyajian data; (4) verifikasi, dan triangulasi dilakukan sebagai teknik dalam pengabsahan data..Hasil penelitian menunjukkan bahwa pertama,gerak dasar anak di masa pandemi covid-19 di TK Negeri Pembina Lengayang berkembang baik. Perkembangan gerak dasar anak di masa pandemi covid-19 di TK Negeri Pembina Lengayang difokuskan dari gerak lokomotor dan gerak manipulatif. Kedua, guru menstimulasi gerak dasar anak dengan kegiatan senam, dan permainan-permainan di masa pandemi dalam kegiatan pembelajaran. Dapat disimpulkan bahwa gerak dasar anak tetap berkembang di masa pandemi, namun, tidak semua terstimulasi dengan baik.
\end{abstract}

\section{Kata Kunci: Gerak Dasar Anak, Pandemi Covid-19}

Received 22-12-2021; Received in revised form 30-12-2021 ; Accepted 31-12-2021

\begin{abstract}
This study aims to determine the development of children's basic movements during the covid-19 pandemic at TK Negeri Pembina Lengayang. This type of research is descriptive qualitative. The research subjects are B1 class children's. Data colection techniques used are field notes, interviews, and documentation. The data analysis technique followed the steps of Miles Huberman, namaely; 1) data collection, 2) data reduction, 3) data presentation and 4) verification. While the data validation technique used is a triangulation technique. The results of the study show that, first the basic movements of children during the covid-19 pandemic at the TK Negeri Pembina Lengayang are developing well. The development of children's basic movements during the covid-19 pandemic in the coach is focused on locomotor movements and manipulative movemens. Second, the teacher stimulates children's basic movements with gymnastics, and games during the pandemic in learning activities. It can be concluded that children's basic movements continue to develop during the pandemic, but not all are stimulated properly.
\end{abstract}

Keywords: Child's basic movement, Covid-19 pandemic. 
J-SANAK: Jurnal Kajian Anak

(p-ISSN: 2686-5343 |e-ISSN: 2715-7989)

Vol. (3)(01), (Juli-Desember)(2021), (Halaman)(48-57)

DOI: https://doi.org/10.24127/j-sanak.v3i01.1404

\section{A. PENDAHULUAN}

Pembelajaran Anak Usia Dini (PAUD) ialah salah satu strategi pembangunan sumber energi manusia serta ialah titik sentral serta sangat mendasar. Bagi Mansur (2011),sekelompok anak yang berada dalam proses perkembangan dan pertumbuhan yang unik disebut dengan anak usia dini. Anak memiliki kecerdasan (intelligence quotient (IQ), emosional quotient (EQ), kecerdasan spiritual (SQ) termasuk mode perkembangan dan pertumbuhan (koordinasi motorik halus dan aktif), energi berpikir, energi kreatif, bahasa dan komunikasi. Atau kecerdasan religi (RQ), tergantung tingkat perkembangan dan pertumbuhan anak. Perkembangan serta pertumbuhan anak Usia dini butuh ditunjukan pada peletakkan dasar-dasar yang pas untuk perkembangan serta pertumbuhan manusia seutuhnya. Pada hakikatnya pembelajaran anak Usia dini menyajikan konsep belajar sembari bermain. Pendidikan ditunjukan pada pengembangan serta penyempurnaan kemampuan keahlian yang dipunyai anak.

Lewat Kementerian Pendidikan serta Kebudayaan Pemerintah sudah melarang sekolah-sekolah buat melakukan pendidikan tatap muka serta memerintahkan buat melakukan pendidikan tatap muka serta memerintahkan buat menyelenggarakan pendidikan secara (Pesan Edaran Kemendikbud Nomor 4 tahun 2020) tentang penerapan kebijakan pembelajaran dalam masa darurat penyebaran Corronavirus Disease (Covid-19) yang memuat panduan proses belajar di rumah melalui pembelajaran jarak jauh atau daring. Hal ini bertujuan untuk memungkinkan anak-anak memiliki pengalaman belajar yang bermakna tanpa beban menyelesaikan semua pertunjukan kursus untuk peningkatan kelas atau kelulusan. Belajar di rumah bisa fokus mempelajari kecakapan hidup, termasuk mengatasi covid-19.

Menjelang penerapan tahun ajaran serta tahun akademik baru 2020/2021, kemendikbud bersama 3 departemen yang lain, ialah departemen agama, departemen kesehatan, serta departemen dalam negara menyusun panduan penyelenggaraan pendidikan. Panduan ini dimaksudkan buat membagikan rasa nyaman kepada warga dengan pembukaan satuan pembelajaran buat pendidikan tatap muka. Pemerintah wilayah, kantor daerah departemen agama provinsi serta/ataupun, kantor departemen agama kota atau kabupaten cocok dengan kewenanggannya yang berada pada zona hijau bisa melaksanakan pendidikan tatap muka di satuan pembelajaran secara bertahap sepanjang masa transisi untuk satuan pembelajaran yang telah penuhi seluruh catatan cek serta merasa siap. Periode transisi berlangsung dua bulan sejak awal pendidikan tatap muka di unit pembelajaran. Agenda pendidikan menentukan jumlah jam belajar setiap hari dan jumlah hari dalam seminggu dengan distribusi kelompok belajar yang ditetapkan oleh unit pembelajaran, selalu mengamati kesehatan dan keselamatan warga 
J-SANAK: Jurnal Kajian Anak

(p-ISSN: 2686-5343 |e-ISSN: 2715-7989)

Vol. (3)(01), (Juli-Desember)(2021), (Halaman)(48-57)

DOI: https://doi.org/10.24127/j-sanak.v3i01.1404

belajar. Dengan senantiasa mempraktikkan protocol kesehatan, terpaut kesiapan, melaksanakan pendidikan tatap muka di satuan pembelajaran.

Pendidikan tatap muka pada waktu pandemi covid-19 membuat ruang gerak anak terbatas dari saat sebelum pandemi covid-19 serta kurang terstimulasi dengan baik. Banyaknya aktivitas di luar ruangan yang ditiadakan menimbulkan anak tidak dapat melaksanakan banyak aktivitas yang bisa meningkatkan aspek- aspek pertumbuhan anak semacam motorik. Terdapat sebagian aspek keahlian anak yang wajib distimulasi pada anak semenjak Usia dini, salah satunya ialah gerak dasar. Pendidikan anak usia dini yang efektif harus didukung oleh suasana belajar yang kondusif. Tidak hanya itu, pembelajaran anak Usia dini merupakan pembelajaran yang sediakan program pengembangan untuk anak yang bertujuan buat menolong meningkatkan bermacam kemampuan baik raga ataupun Psikologi, termasuk moralitas, agama, masyarakat, emosi, kemandirian, kognisi, bahasa, tubuh, olahraga, dan seni buat mempersiapkan anak merambah pembelajaran lebih lanjut. Keahlian gerak dasar anak sangat butuh dibesarkan dari Usia dini supaya anak bisa hidup cocok dengan perkembangannya (Depdiknas, 2007). Tujuan pembinaan motorik aktif di taman kanak-kanak adalah untuk memperagakan dan melatih gerak motorik aktif, meningkatkan keterampilan manajemen, mengendalikan koordinasi gerak jasmani, meningkatkan keterampilan jasmani dan pola hidup sehat, sehingga tercapai perkembangan jasmani yang sehat, kuat, dan terampil yang diajarkan sesuai dengan bakatnya. Dukungan untuk perkembangan fisik anak mendapatkan pelatihan olahraga dasar yang nantinya akan mendukung perkembangan motorik mereka. Anak yang mempunyai pertumbuhan motorik yang bagus hendak mempunyai keahlian gerak dasar yang bagus. Gerak dasar merupakan keahlian buat melaksanakan tugas tiap hari yang meliputi gerak jalur, lari, lompat, lempar.

Menurut (Syahrial, 2015) gerak dasar adalah keterampilan yang menghubungkan otak, otot-otot lengan dan kaki, dan digunakan untuk mencapai tujuan latihan atau olahraga, seperti melempar bola, melompat atau menyelam ke dalam air, atau perlindungan penyeimbang. Bagi (Gallahue, Oznum serta Goodway, 2012) keahlian gerak dasar yang sangat berarti untuk anak Usia dini dibagi atas 2 wujud, ialah lokomotor, serta objek kontrol. Gerak lokomotor bisa dimaksud selaku gerak memindahkan badan dari satu tempat ke tempat lain (Yuddanto, 2011). Wujud gerak lokomotor antara lain berjalan, berlari, berjingkat, melompat serta meloncat, berderap, merayap serta memanjat. Sedangkan (Kamtini, Husni dilansir oleh Yuningsih, 2015) mengemukakan kalau gerak manipulatif merupakan gerak yang mengaitkan aksi mengendalikan sesuatu objek spesialnya tangan serta kaki. Contohnya menggiring, menangkap, melontar, dan menendang. Bersumber pada kasus diatas, hingga periset tertarik mau mengkaji dalam suatu riset yang bertajuk "Perkembangan Gerak Dasar Anak di Masa Pandemi Covid-19 di TK Negara Pembina Lengayang”. 
J-SANAK: Jurnal Kajian Anak

(p-ISSN: 2686-5343 |e-ISSN: 2715-7989)

Vol. (3)(01), (Juli-Desember)(2021), (Halaman)(48-57)

DOI: https://doi.org/10.24127/j-sanak.v3i01.1404

\section{B. METODOLOGI}

Jenis penelitian yang digunakan dalam penelitian ini adalah kualitatif dengan pendekatan studi deskriptif. Merupakan prosedur penelitian yang menghasilkan data-data deskriptif berupa kata-kata tertulis maupun lisan dari informan penelitian dan perilaku obyek penelitian yang diamati. Dalam penelitian ini tidak ada perlakuan yang ditambahkan atau dikurangi dalam perolehan data di lapangan. Penelitian ini mengambarkan suatu gejala, kondisi dan sifat situasi secara apa adanya tanpa adanya manipulasi pada waktu penyelidikan lapangan dilakukan.

Tujuanpenelitian ini adalah melukiskan variabel atau kondisi obyek yang diamati secara apa adanya tanpa adanya manipulasi. Metode penelitian kualitatif menurut Sugiyono (2012) adalah metode penelitian yang berlandaskan pada filsafat postpositivisme, digunakan untuk meneliti pada kondisi obyek yang alamiah, (sebagai lawannya adalah eksperimen) dimana peneliti adalah sebagai intrumen kunci, teknik pengumpulan data dilakukan secara trianggulasi (gabungan), analisis data bersifat induktif/kualitatif, dan hasil penelitian kualitatif lebih menekankan makna dari pada generalisasi. Deskriptif adalah jenis penelitian yang digunakan untuk menganalisis data dengan cara mendeskripsikan atau menggambarkan data yang telah terkumpul sebagaimana adanya. Subyek penelitian ini ialah anak-anak kelas B1 TK Negeri Pembina Lengayang. Informan penelitian ini adalah guru TK Negeri Pembina Lengayang.

Pengumpulan data menggunakan metode wawancara, catatan lapangan,dan dokumentasi. Metode analisis informasi menjajaki langkah Miles serta Huberman ialah (1) Pengumpulan Informasi;(2) Pengurangan Informasi;(3) Penyajian Informasi; dan (4) Verifikasi. Sebaliknya, metode keabsahan informasi yang digunakan dalam bentuk metode triangulasi. Sugiyono (2014) triangulasi merupakan sebagai teknik pengumpulan data yang mengharuskan data yang sebenar-benarnya sehingga dibutuhkan pemeriksaan kembali data yang diperoleh. Triangulasi yang digunakan adalah triangulasi sumber. Triangulasi sumber ialah teknik pengumpulan data yang diperoleh dari berbagai sumber yang saling berbeda pendapat lalu dideskripsikan mana pendapat yang mempunyai kesamaan. Teknik triangulasi sumber ditemukan dari berbagai sumber sehingga dapat membandingkan hasil catatan lapangan, wawancara, anatar berbagai sumber dan juga dokumen.

\section{HASIL PENELITIAN}

Berdasarkan pada hasil penelitian, diketahui bahwa aspek perkembangan gerak dasar anak berkaitan erat dengan kemampuan gerak sehari-hari.Motorik ialah gerak badan yang ditimbulkan oleh aksi, sebaliknya pertumbuhan motorik bisa diucap selaku pertumbuhan dari faktor kematangan serta pengendalian gerak badan 
J-SANAK: Jurnal Kajian Anak

(p-ISSN: 2686-5343 |e-ISSN: 2715-7989)

Vol. (3)(01), (Juli-Desember)(2021), (Halaman)(48-57)

DOI: https://doi.org/10.24127/j-sanak.v3i01.1404

(Yuliansih,2015)". Bagi Berk (Suyadi,2010), Terus menjadi anak meningkat berusia serta kokoh badannya, hingga style geraknya terus menjadi sempurna. Bagi Rahayu (2019) Gerak merupakan gerak anggota tubuh secara agresif ataupun keras. Gerak dasar merupakan keahlian buat melaksanakan tugas tiap hari yang meliputi gerak jalur, lari, lompat, serta lempar. Bagi Bakhtiar Syahrial (2015), gerak dasar adalah keterampilan yang menghubungkan otak, otot-otot lengan dan kaki, dan digunakan untuk mencapai tujuan latihan atau olahraga, seperti melempar bola, melompat atau menyelam ke dalam air, atau perlindungan penyeimbang. Keahlian gerak dasar bisa dipecah jadi 3, ialah gerak lokomotor, gerak non lokomotor, serta gerak manipulatif. Keterampilan gerak lokomotor adalah upaya untuk berpindah dari satu tempat ke tempat lain, seperti berlari, melompat, dan melompat. Keterampilan gerak nonlokomotor adalah olahraga yang telah dicoba di lapangan, seperti membungkuk, memutar, mengayun, dll.

Sebaliknya keahlian gerak manipulatif merupakan gerak buat berperan melaksanakan suatu wujud gerak dari anggota tubuhnya secara lebih terampil, semacam; melontarkan, menangkap, menyepak, serta menendang. Tetapi bagi Gallahue, Oznum serta Goodway (2012), keahlian gerak dasar yang sangat berarti untuk anak Usia dini dibagi atas 2 wujud, ialah lokomotor serta objek kontrol. Lokomotor ialah gerak di mana tubuh dipindahkan dari satu titik ke titik lain. Tindakan tersebut antara lain: lari (running), pacu kuda (gallop), melompat berjinjit (hopping), berlari dengan melompat (jumping), dan jumping horizontal (melompat ke satu arah). Sebaliknya objek kontrol ialah adalah objek manipulasi gerakan, termasuk gerakan ini; melempar bola dari atas (Overarm throw), menendang bola (kicking), menendang bola keluar sebelum bola menyentuh tanah (punting), memukul bola yang diam(sidearm striking a stationary ball), memukul bola dari atas dengan posisi diam (overarm striking a stationary ball), menggenggam, meremas (grasping), serta menangkap (catching). Bagi Hidayat (2017), keterampilan yang berguna untuk memindahkan tubuh dari satu tempat ke tempat lain, menyebabkan perpindahan semacam berjalan, berlari, melompat, hop, skip, slide, serta lain-lain disebut dengan gerak lokomotor.

Bagi K. Elien Allen serta Lynn R. Marotz,(2010):'Pertumbuhan gerak lokomotor anak Usia 5- 6 tahun, ialah:(a) Melompat; (b) meloncat atau berjalan ke depan 10 kali tanpa jatuh; (c) Berjalan berjinjit selama lebih dari 20 detik; (d) Berlari sejauh 2 meter dengan atau tanpa hambatan. Samsudin dilansir oleh Yuningsih (2015) mengemukakan kalau gerak manipulatif lebih mengaitkan tangan serta kaki, namun bagian lain dari badan kita pula digunakan. Perihal ini cocok dengan komentar Kamtini serta Husni dikutip oleh Yuningsih (2015) mengemukakan kalau gerak manipulatif merupakan gerak yang mengaitkan aksi mengendalikan sesuatu objek spesialnya tangan serta kaki. Bagi Lutan (2001) melaporkan kalau keahlian gerak dasar bisa diterapkan dalam aneka game, berolahraga, serta kegiatan jasmani yang dicoba dalam kehidupan tiap hari. Lewat 
J-SANAK: Jurnal Kajian Anak

(p-ISSN: 2686-5343 |e-ISSN: 2715-7989)

Vol. (3)(01), (Juli-Desember)(2021), (Halaman)(48-57)

DOI: https://doi.org/10.24127/j-sanak.v3i01.1404

kegiatan bermain, sangatlah pas buat meningkatkan keahlian gerak dasar anak di sekolah, sebab pada dasarnya dunia kanak-kanak merupakan bermain. Simcoe Muskoka District Health Unit (2012), mengemukakangerak dasar memiliki manfaat bagi kesehatan anak, perkembangan motorik anak, perkembangan kognitif anak, kemampuan sosial anak, dan perkembangan emosional anak. Perkembangan adalah kemampuan untuk menuju proses menjadi lebih matang baik secara fisik ataupun fsikis. Gerak adalah kemampuan anak untuk beraktifitas dalam melakukan sesuatu kegiatan sehari-hari. Gerak dasar adalah aspek kemampuan fisik motorik yang perlu dikembangkan dalam diri anak. Berdasarkan hasil penelitian diketahui perkembangan gerak dasar anak di masa pandemi Covid-19 di TK Negeri Pembina Lengayang untuk kemampuan gerak dasar anak berkembang baik.

\section{Apa-apa Saja Perkembangan Gerak Dasar Anak di Masa Pandemi Covid- 19 di TK Negeri Pembina Lengayang}

Penelitian ini dikuatkan oleh pendapat ahli yaitu bagi Gallahue Ozmun serta Goodway (2012), keahlian gerak dasar yang sangat berarti untuk anak Usia dini dibagi atas 2 wujud, ialah lokomotor, serta objek kontrol. Adapun perkembangan gerak dasar anak di masa pandemi di TK Negeri Pembina Lengayang adalah sebagai berikut:

a. Gerak Lokomotor

Pada masa pandemi covid-19, kegiatan gerak dasar lokomotor di TK Negeri Pembina Lengayang adalah dengan gerakan menirukan gerakan jalan/berlari dengan suara binatang seperti ayam, kuda, kelinci, senam pagi, permainan melompat dengan dua arah, dan bermain dengan teman. Sejalan dengan pendapat Smith dan Pellegrini (2013) menyatakan bahwa permainan lokomotor terdiri dari bermain (lari, mendaki) yang melibatkan aktifitas tubuh yang didukung oleh otot, kekuatan, daya tahan dan keterampilan. Pada saat melakukan permainan menirukan lari binatang kuda, kelinci, dan ayam anak-anak melakukan gerak dan berpindah tempat. Semua anak terlihat hampir bisa melakukannya dengan mirip, dan ada beberapa anak yang juga dibantu oleh guru. Melalui kegiatan menirukan gerak, jalan/lari binatang dapat mengembangkan gerak dasar lokomotor anak, dengan berbagai gerak yang cobakan anak. Kegiatan tersebut juga sangat menyenangkan bagi anak-anak dan dapat juga anakanak dapat lebih mengekpresikan dirinya dan lebih percaya diri.

Melalui kegiatan senam pagi di masa pandemi di TK Negeri Pembina Lengayang dapat mengembangkan gerak dasar lokomotor pada anak usia dini. Wang et al. (2010), menemukan ketika anak diberikan latihan uang teratur dan diberikan kesempatan untukmengeksplorasi anak sesuai eksplorasi pelatih, kunci gerakan lokomotor anak akan terus meningkat. Sejalan dengan penelitian tersebut bahwa melalui senam anak- 
J-SANAK: Jurnal Kajian Anak

(p-ISSN: 2686-5343 |e-ISSN: 2715-7989)

Vol. (3)(01), (Juli-Desember)(2021), (Halaman)(48-57)

DOI: https://doi.org/10.24127/j-sanak.v3i01.1404

anak dapat mengembangkan gerak dasar lokomotornya dengan berbagai gerakan melalui latihan senam yang teratur dan anak mengikuti instrukturnya. Kegiatan senam di sekolah dimasa pandemi dilakukan satu kali dalam dua minggu. Pertumbuhan gerak dasar lokomotor sangat dipengaruhi oleh jasmani. Hal ini mirip dengan latihan fisik dimana anak mencoba membiasakan untuk menggerakkan anggota tubuhnya dari urutan gerakan lokomotornya (Lemos et al., 2012).

Di sekolah guru pula meningkatkan gerak dasar lokomotor anak bisa nampak pada permainan-permainan, semacam game melompat 2 arah. Lewat game melompat 2 arah tanpa disadari kanak-kanak telah meningkatkan gerak dasar lokomotor. Sejalan dengan pernyataan Santre (2005): "Dengan banyaknya gerakan yang disalurkan dapat membuat anak-anak lebih sehat dan meningkatkan pergerakan lokomotor dan anakanak untuk meningkatkan kemandirian, rasa yakin dirinya, kerja sama dan pertumbuhan intelektual". Aktivitas game ialah salah satu metode buat tingkatkan gerak lokomotor anak, sebab tiap metode yang dicoba oleh guru diiringi pula oleh tiap anak. Gerak dasar lokomotor bisa dibesarkan secara optimal oleh anak di kala anak mempunyai anggapan yang kokoh kalau ia bisa melaksanakannya dengan baik di dikala melaksanakan latihan (Mukherjee et al., 2011).

b. Objek Kontrol

Objek kontrol merupakan gerakan manipulasi objek. Objek kontrol terkait dengan objek itu sendiri yang harus dimanipulasi sedemikian rupa untuk membentuk keterampilan. Dimasa pandemi di TK Negeri Pembina Lengayang terlihat kegiatan gerak dasar manipulatif melalui permainan. Permainan yang dilakukan adalah permainan melempar batu kecil dengan bola, permainan memasukkan atau melempar bola ke dalam keranjang, permainan menangkap dan melempar bola secara berpasangan. Pola permainan anak juga memiliki unsur manipulasi gerakan (Julianur, 2017). Samsudin (2016) mengemukakan bahwa keterampilan memanipulasi benda termasuk menangkap bola (menerima bola) dan mendorong bola (melempar,memukul, menendang) merupakan keterampilan penting yang dapat dicapai dengan menggunakan bola plastik. Gerakan melompat dapat diajarkan, melompat atau menggiring bola atau bola plastik (bola sedang) yang terbuat dari bantalan karet.Sejalan dengan pendapat tersebut melalui permainan melempar batu kecil dengan bola tanpa disadari anak-anak telah mengembangkan gerak manipulatif. Melalui permainan melempar batu dengan bola terlihat anak-anak sangat hati-hati dan konsentrasi dalam melakukan permainan. Beberapa anak tepat sasaran dalam melempar, dan ada beberapa anak yang harus berulang dalam melempar. Kemampuan 
J-SANAK: Jurnal Kajian Anak

(p-ISSN: 2686-5343 |e-ISSN: 2715-7989)

Vol. (3)(01), (Juli-Desember)(2021), (Halaman)(48-57)

DOI: https://doi.org/10.24127/j-sanak.v3i01.1404

semakin meningkat ketika anak semakin sering mengulang,semakin bagus posisi melempar, dan dapat tepat sasaran batu.

Gerak objek kontrol juga terlihat di masa pandemi pada kegiatan permainan memasukkan atau melempar bola ke dalam keranjang. Permainan ini dapat mengembangkan gerak manipulatif pada anak usia dini. Senada dengan Hidayat (2015) perkembangan fisik gerakan manipulatif adalah gerakan yang dikembangkan ketika anak sedang mengendalikan objek yang berbeda. Melalui permainan memasukkan atau melempar bola ke dalam keranjang anak telah melakukan gerak manipulatif. Gerak manipulatif dapat terlihat di saat anak dapat menguasai bola dan dapat melempar bola ke dalam keranjang. Melalui permainan tersebut selain dapat mengembangkan gerak manipulatif, tetapi juga dapat mengembangkan bahasa, motorik, emosional, dan kognitif pada anak usia dini. Salah satu dari kemampuan manipulatif yang sangat diperlukan ialah keterampolan melontarkan dan menangkap. Sejalan dengan komentar Sumantri (2005)keahlian mengunakan otot- otot besar ini untuk anak Usia dini terkategori pada keahlian gerak dasar, keahlian ini dicoba buat tingkatkan mutu hidupnya". Melontarkan adalah keterampilan manipulatif yang menggunakan satu atau dua tangan untuk melempar benda yang menghindari tubuh ke lawan atau ruangan tertentu.Aktivitas melempar bola menghasilkan koordinasi tangan-mata selama proses melempar. Gerakan yang menghentikan momentum suatu obyek dan meningkatkan kontrol obyek dengan satu atau dua tangan disebut menangkap.Melalui kegiatan menangkap bola, maka terjadi koordinasi antara mata dan tangan pada saat menangkap bola.

\section{Bagaimana Cara Guru Menstimulasi Gerak Dasar Anak di Masa Pandemi Covid-19 di TK Negeri Pembina Lengayang}

Beberapa cara yang dapat dilakukan pendidik dalam memberikan rangsangan terhadap gerak dasar anak di masa pandemi covid-19 di TK Negeri Pembina Lengayang adalah guru menyediakan permainan pada saat kegiatan pembelajaran, dan kegiatan senam pagi. Sejalan dengan pendapat Lutan (2001) melaporkan kalau keahlian gerak dasar bisa diterapkan dalam aneka game, berolahraga, serta kegiatan jasmani yang dicoba dalam kehidupan tiap hari. Lewat kegiatan bermain, sangatlah pas buat meningkatkan keahlian gerak dasar anak di sekolah. Berdasarkan hasil penelitian pada kegiatan gerak dasar anak di masa pandemi yang peneliti dapatkan dari catatan lapangan, wawancara, pada gerak dasar anak beberapa cara guru terlihat dalam menstimulasinya diantaranya adalah melalui kegiatan permainan menirukan gerak/jalan binatang, senam pagi, permainan melompat dengan dua arah, permainan melempar batu kecil dengan batu, permainan melempar dan menangkap bola secara berpasangan, dan 
J-SANAK: Jurnal Kajian Anak

(p-ISSN: 2686-5343 |e-ISSN: 2715-7989)

Vol. (3)(01), (Juli-Desember)(2021), (Halaman)(48-57)

DOI: https://doi.org/10.24127/j-sanak.v3i01.1404

permainan memasukkan atau melemparkan bola ke dalam keranjang. Guru juga menstimulasi gerak dasar anak di masa pandemi melalui senam pagi. Senam merupakan cabang olahraga yang didirikan oleh keterampilan gerak yang sangat unik. Dilihat dari gerak secara umum, senam secara lengkap diwakili oleh gerakgerak dasar yang membangun pola gerak yang lengkap, dari mulai pola gerak lokomotor, gerak nonlokomotor, serta manipulatif.

Sejalan dengan pendapat Abdul Kadir (2010) berpendapat bahwa melalui aktifitas jasmani gerak dan lagu dapat memberikan sumbangan yang besar untuk menyeimbangkan otak anak usia dini, dengan memadukan aktivitas jasmani dan aktifitas mendengarkan musik ataupun menyanyi, dapat membantu perkembangan otak. Senam mengandung gerakan-gerakan lokomotor, nonlokomotor, dan manipulatif yang dianggap mampu meningkatkan aspek kekuatan, kecepatan, power, daya tahan, kelincahan, serta keseimbangan pada anak.

\section{KESIMPULAN}

Hasil penelitian yang telah peneliti lakukan tentang perkembangan gerak dasar anak di masa pandemi covid-19 di UPT TK Negeri Pembina Lengayangdimasa pandemi gerak dasar anak tetap berkembang baik dengan beberapa kegiatan yang dapat mengembangkan gerak dasar anak seperti melalui senam pagi dan permainan-permainan. Perkembangan gerak dasar anak terdiri dari gerak lokomotor dan gerak manipulatif. Perkembangan gerak lokomotortetap berkembang seperti biasa dengan berbagai kegiatan seperti menirukan gerak/lari binatang, senam, dan permainan melompat dengan dua arah. Sedangkan perkembangan objek kontrol anak dimasa pandemi juga tetap berkembang dengan kegiatan seperti dengan berbagai permainan melempar batu kecil dengan bola, permainan melempar dan menangkap bola secara berpasangan, dan permainan memasukkan atau melempar bola ke dalam keranjang. Dapat disimpulkan gerak dasar anak tetap berkembang di masa pandemi, namun tidak semua dapat terstimulasi dengan baik.

\section{E. DAFTAR PUSTAKA}

Bakhtiar Syahrial. (2015). Merancang Pembelajaran Gerak Dasar Anak. Padang: UNP Press.

Sulaksono. "Keterampilan Gerak Dasar Pada Anak dalam Pendidikan Jasmani dan Olahraga".Online:Artikel:ArtikelDaspen.https://id.scrib.com/document/34 0241334/Artikel-Daspen.

Pradipta.( 2017). "Strategi Peningkatan Keterampilan Gerak Untuk Anak Usia Dini Taman Kanak-Kanak B”. Online: Jurnal Jendela Olahraga Vol 2, N0.1 (2017). ISSN 2527-9580. 
J-SANAK: Jurnal Kajian Anak

(p-ISSN: 2686-5343 |e-ISSN: 2715-7989)

Vol. (3)(01), (Juli-Desember)(2021), (Halaman)(48-57)

DOI: https://doi.org/10.24127/j-sanak.v3i01.1404

Hidayat, A. (2017). "Peningkatan Aktivitas Gerak Lokomotor, Nonlokomotor, dan Manipulatif Mengunakan Model Permainan Pada Siswa Sekolah Dasar". Jurnal Pendidikan Jasmani Dan Olahraga . https://doi.org/10.17509/jpjo.v2i2.8175

Husnul Hadi, dkk. (2017). "Katerampilan Gerak Dasar Anak Usia Dini Pada Taman Kanak-Kanak (TK) DI Kota Surakarta". Jurnal Seminar Nasional Hasil Penelitian (SNHP) VII Lembaga Penelitian dan Pengabdian Kepada Masyarakat Universitas PGRI Semarang ISBN 978-602- 140205-4), 651-652.

Kamtini. (2014). Motorik Kasar Anak Usia Dini. Medan: Media Persabda.

Lutan, Rusli (2001). Asas-Asas Pendidikan Jasmani. Jakarta: Depdiknas.

Rahayu,R.J. (2019). "Upaya Meningkatkan Hasil Belajar Keterampilan Manipulatif Lengan pada Pembelajaran Model Pendidikan Gerak Berformat Permainan". TEGAR: Journal of Teaching Physical Education in Elementary School,2(2),1-6. https://doi.org/10.5539/tegar.v6n2p1

Rina Tri Handayani, dkk. (2020). "Pandemi Covid-19, Respon Imun Tubuh, HERD IMMUNITY”. Jurnal Ilmiah Stikes Kendal Volume 10 (No.3), Hal 374.

Smith, Peter, K.,\&Pellegrini, A. (2013). Learning Through Play. Encyclopedia on early Childhood Development. (pp.1-5).

Widiarti, dkk. (2021). "Peningkatan Kemampuan Gerak Dasar Lokomotor Anak Melalui Modifikasi Seni Tradisional Burok". (Online):Jurnal Obsesi: Jurnal Pendidikan Anak Usia Dini.ISSN: 2549-8959.

Yuliansih. (2015). Pengaruh Senam Irama Terhadap Kemampuan Motorik Anak Usia 5 Tahun. Universitas Muhammadiyah: Surakarta. 